\title{
Analisis Kecepatan Kendaraan Akibat Hambatan Samping (Studi Kasus: Jl. Mayor Abd. Karta Wirana Kota Jambi di sekitar Lippo Mall)
}

\author{
Emelda Raudhati ${ }^{1}$, Ellyta Mona ${ }^{2}$ \\ ${ }^{1,2}$ Teknik Sipil Universitas Batanghari \\ Correspondence email: emeldaraudhati@gmail.com
}

\begin{abstract}
Abstrak. Aktivitas perkotaan mengakibatkan meningkatnya kepemilikan kendaraan dan perubahan tata guna lahan yang mengakibatkan kemacetan. Salah satu penyebabnya adalah faktor hambatan samping yang berakibat berkurangnya kecepatan. Penelitian ini bertujuan untuk menganalisis kecepatan kendaraan akibat hambatan samping dengan metode MKJI 1997 dan analisis distribusi kumulatif kecepatan dengan metode statistik. Penelitian ini dilakukan pada ruas Jalan Mayor Abd. Karta Wirana Kota Jambi disekitar Lippo Mall. Hasil menunjukkan bahwa total hambatan samping untuk kejadian perhari pada hari Rabu sebesar 1175,34 dengan kejadian hambatan terendah pada pejalan kaki sebesar 48,39 dan kejadian hambatan tertinggi pada kendaraan masuk dan keluar sebesar 790,32. Kelas hambatan samping pada ruas Jalan Mayor Abd. Karta Wirana, sesuai MKJI 1997, termasuk kelas yang tinggi (VH) dengan frekuensi bobot kejadian melebihi >900 kejadian per hari. Sedangkan kecepatan saat terganggu diperoleh rata-rata $11,56 \mathrm{~km} / \mathrm{jam}$ berada pada kecepatan terendah interval $10-11 \mathrm{~km} / \mathrm{jam}$ dan tertinggi $12-13$ $\mathrm{km} / \mathrm{jam}$. Kecepatan saat tak terganggu dengan rata-rata 30,32 km/jam berada pada kecepatan terendah interval $20-24 \mathrm{~km} / \mathrm{jam}$ dan tertinggi $36-40 \mathrm{~km} / \mathrm{jam}$. Selisih kedua kecepatan ini menyatakan bahwa hambatan samping sangatlah besar pengaruhnya terhadap kecepatan (penurunan kecepatan yang sangat signifikan sebesar 61,87\%)
\end{abstract}

Kata kunci: MKJI 1997; Distribusi Kumulatif; Hambatan Samping; Kecepatan

Abstract. This study aims to analyze the vehicle speed due to side friction with the MKJI 1997 method and the analysis of the cumulative distribution of speed using statistical methods. This research was conducted on Jalan Mayor Abd. Karta Wirana Jambi City around Lippo Mall. The results show that the total side friction for events per day on Wednesday is 1175.34 with the lowest incidence of resistance on pedestrians at 48.39 and the highest incidence of friction on incoming and outgoing vehicles of 790.32. Side friction class on Jalan Mayor Abd. Karta Wirana, according to MKJI 1997, is in a high class (VH) with a frequency of weight events exceeding > 900 events per day. While the speed when disturbed is obtained an average of 11, $56 \mathrm{~km} /$ hour is at the lowest speed interval $10-11 \mathrm{~km} /$ hour and the highest speed is $12-13 \mathrm{~km} /$ hour. The average of undisturbed speed of 30.32 $\mathrm{km} / \mathrm{h}$ at the lowest speed interval of 20-24 km/ hour and the highest is 36-40 km/ hour. The difference between these two speeds states that the side drag has a very large effect on speed (a very significant decrease in speed is $61.87 \%$ )

Kata key: MKJI 1997; Cumulative Distribution; Side friction; Speed

\section{PENDAHULUAN}

Peningkatan jumlah penduduk serta aktivitas perkotaan mengakibatkan semakin meningkatnya kepemilikan kendaraan dan perubahan tata guna lahan yang mengakibatkan kemacetan. Salah satu penyebab terjadinya kemacetan adalah faktor hambatan samping, hal ini terkait dengan tata guna lahan di sepanjang jalan tersebut. Hambatan samping yang terjadi dapat berupa pejalan kaki, angkutan umum dan kendaraan lain yang berhenti, kendaraan yang berjalan lambat, kendaraan yang keluar dan masuk dari lahan di samping jalan.

Adapun Penelitian ini dilakukan pada Jalan Mayor Abd. Karta Wirana di Kota Jambi yang terbilang cukup padat arus lalu lintasnya. Di Sepanjang jalan ini ada kegiatan perdagangan dan kuliner yang mengakibatkan banyak penjual dan pembeli, serta kendaraan yang berhenti di ruas jalan tesebut. Di Jalan ini juga berdiri sebuah pusat perbelanjaan Lippo Mall, selain itu juga jalan ini merupakan salah satu akses menuju ke arah pasar tradisional. Berdasarkan pengamatan di lapangan, kondisi jalan tersebut sering terjadi hambatan samping yaitu adanya pejalan kaki yang menyeberang, kendaraan yang keluar masuk pusat perbelanjaan menyebabkan ruas Jalan menjadi lebih sempit, sehingga kecepatan berkurang, waktu tempuh bertambah. Oleh karena itu perlu dilakukan analisis terkait permasalahan di lapangan dengan menganalisis kecepatan kendaraan akibat hambatan samping.

Penelitian ini bertujuan menganalisis kecepatan kendaraan akibat hambatan samping dengan metode MKJI 1997 dan analisis distribusi kumulatif kecepatan dengan metode statistik. Penelitian terdahulu yang sejenis mengenai hambatan samping dan kecepatan telah dilakukan oleh Tataming dkk (2014) menyatakan bahwa penyebab utama kemacetan yang terjadi di ruas jalan Sarapung adalah parkir dan kendaraan berhenti yang memberikan kontribusi sebesar 25,36\%. Irfan (2017) menyatakan hambatan samping dengan kategori tinggi akibat oleh kendaraan parkir, kendaraan keluar masuk yang dipengaruhi oleh banyaknya aktivitas pedagang kaki lima. Demikian juga Winayati (2016), menyimpulkan bahwa parkir dan kendaraan berhenti di badan jalan merupakan faktor yang paling berpengaruh terhadap hambatan samping. 
Hambatan Samping adalah aktivitas samping jalan yang dapat menimbulkan konflik dan berpengaruh terhadap pergerakan arus lalu lintas serta menurunkan fungsi kinerja jalan. Menurut Manual Kapasitas Jalan Indonesia (MKJI, 1997) ada empat tipe hambatan samping yaitu 1) Pejalan kaki dan penyeberang jalan; 2) Jumlah kendaraan berhenti dan parkir; 3) Jumlah kendaraan bermotor yang masuk dan keluar dari lahan samping jalan; 4) arus kendaraan lambat, yaitu arus total (kend/jam) sepeda, becak, delman, pedati, traktor dan sebagainya. Hal senada disampaikan bahwa salah satu faktor yang dapat mempengaruhi penurunan kapasitas jalan adalah lajur lalu lintas dan bahu jalan yang sempit atau halangan lainnya pada kebebasan samping. Hambatan terbukti samping sangat berpengaruh pada kapasitas dan kinerja jalan yang mencakup: pejalan kaki, pemberhentian angkutan umum dan kendaraan lain serta kendaraan keluar masuk dari lahan samping jalan (Oglesby dan Hicks, 1999)

Menurut Tamin (2000), Hambatan samping adalah aktivitas disamping segmen jalan yang menimbulkan masalah di sepanjang jalan, menghambat kinerja lalu lintas untuk berfungsi secara maksimal. Hambatan samping sangatlah berpengaruh terhadap kapasitas dan kinerja jalan, dimana hambatan samping ada tingkatan kelas dan kriteria jenis hambatan samping yang dikelompokkan sebagaimana Tabel 1 dan Tabel 2.

Tabel 1. Kelas Hambatan Samping

\begin{tabular}{lccl}
\hline $\begin{array}{c}\text { Kelas Hambatan } \\
\text { Samping (SFC) }\end{array}$ & Kode & $\begin{array}{c}\text { Jumlah berbobot kejadian } \\
\text { per 200m/jam (dua sisi) }\end{array}$ & Kondisi Khusus \\
\hline Sangat Rendah & VL & $<100$ & Daerah permukiman; jalan samping tersedia \\
Rendah & L & $100-299$ & Daerah permukiman; beberapa angkutan umum dsb \\
Sedang & M & $300-499$ & Daerah industri; beberapa toko sisi jalan \\
Tinggi & H & $500-899$ & Daerah komersial; aktivitas sisi jalan tinggi \\
Sangat Tinggi & VH & $>900$ & Daerah komersial; aktivitas pasar sisi jalan \\
\hline
\end{tabular}

Sumber: MKJI 1997

Tabel 2. Jenis Hambatan Samping Jalan

\begin{tabular}{lcc}
\hline \multicolumn{1}{c}{ Tipe Kejadian Hambatan Samping } & Simbol & Faktor Bobot \\
\hline Kendaraan parkir & PSV & 1 \\
Kendaraan masuk dan keluar sisi jalan & EEV & 0,7 \\
Keadaan lambat & SMV & 0,4 \\
\hline
\end{tabular}

Sumber: MKJI 1997

Menurut Hobbs (1995), menyatakan bahwa kecepatan adalah laju perjalanan yang dinyatakan dalam kilometer perjam $(\mathrm{Km} / \mathrm{Jam})$, dimana kecepatan dibagi menjadi tiga jenis yaitu:

1. Kecepatan setempat yaitu kecepatan kendaraan pada saat diukur dari suatu tempat yang telah ditentukan.

2. Kecepatan bergerak yaitu kecepatan kendaraan rata-rata pada suatu jalur dimana saat kendaraan bergerak, diperoleh dengan membagi panjang jalur dibagi dengan lama waktu kendaraan bergerak menuju jalur tersebut.

3. Kecepatan berjalan yaitu kecepatan efektif kendaraan yang sedang berjalan antara dua tempat, dimana jarak antara dua tempat dibagi dengan lama waktu kendaraan untuk menyelesaikan perjalanan dengan lama waktu yang mencakup tiap waktu henti yang ditimbulkan oleh waktu hambatan lalu lintas.

Sedangkan menurut MKJI (1997), Kecepatan kendaraan adalah jarak yang dapat ditempuh suatu kendaraan pada suatu ruas jalan dalam satu satuan waktu tertentu, dinyatakan sebagaimana rumus berikut.

$$
V=\frac{d}{t}
$$

Dimana:

$$
\begin{array}{ll}
\mathrm{V} & =\text { Kecepatan }(\mathrm{km} / \mathrm{jam}, \mathrm{m} / \mathrm{detik}) \\
\mathrm{d} & =\text { Jarak tempuh kendaraan }(\mathrm{km}, \mathrm{m}) \\
\mathrm{t} & =\text { Waktu tempuh kendaraan }(\mathrm{jam}, \text { detik) }
\end{array}
$$

Distribusi frekuensi kumulatif adalah distribusi frekuensi yang menunjukkan jumlah frekuensi pada sekelompok nilai tertentu, mulai dari kelompok sebelumnya sampai dengan kelompok tersebut. Distribusi frekuensi dengan panjang kelas yang sama dilakukan melalui tahapan sebagai berikut (Sudjana, 1996):

1. Tentukan rentang, yaitu data terbesar dikurangi data terkecil

2. Tentukan banyak kelas interval yang dibutuhkan, menggunakan aturan Sturges, yaitu banyakkelas $=1+(3,3) \log n$

3. Tentukan panjang kelas interval, dengan aturan 


$$
p=\frac{\text { rentang }}{\text { banyak kelas }}
$$

4. Mulai membuat interval dari data terkecil

\section{METODE}

Metode yang digunakan adalah metode survei yang meliputi survei hambatan samping, survei kecepatan. Dimana survei hambatan samping dilakukan dengan mencatat semua aktivitas kegiatan hambatan samping pada formulir yang telah disediakan, kemudian data diolah menggunakan metode MKJI 1997, sedangkan survei kecepatan dilakukan pada suatu titik pengamatan dilapangan dengan mencatat semua kendaraan yang melintas lokasi pengamatan, kemudian data diolah diperoleh kecepatan, dianalisis menggunakan metode statistik dengan distribusi kumulatif kecepatan. Survei dilaksanakan pada hari kerja diambil hari Rabu pada tanggal 4 Maret 2020 pada jam $06.00-22.00 \mathrm{Wib}$.

Adapun denah lokasi penelitian sebagaimana lay out ditampilkan pada Gambar 1.

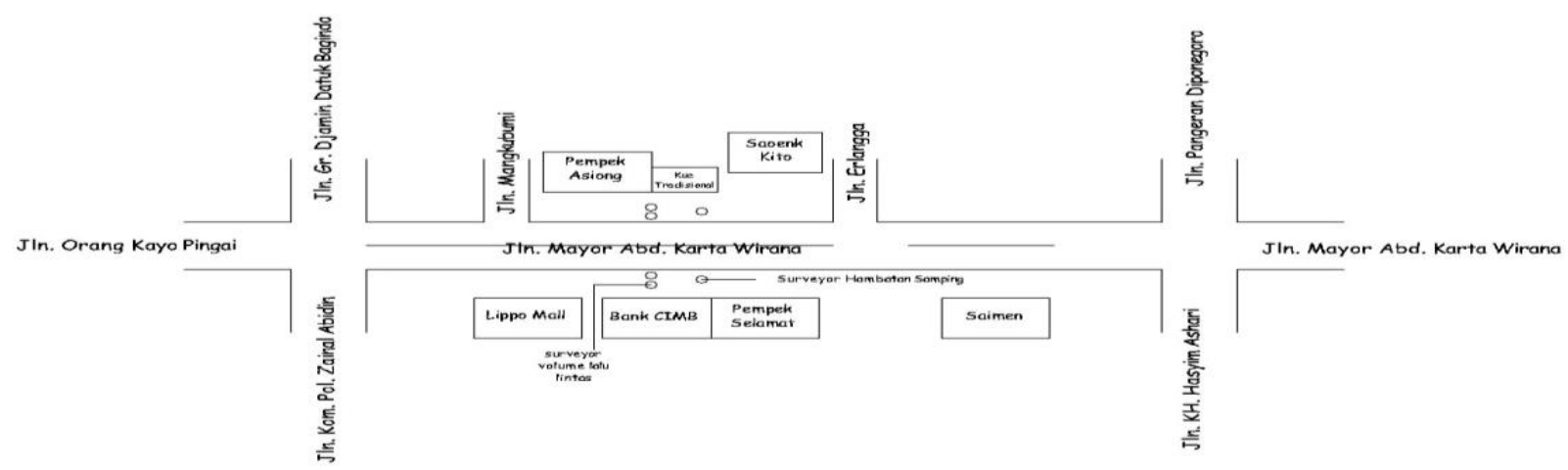

Gambar 1. Lokasi Penelitian

Berdasarkan Gambar 1. Diperoleh data geometrik pada ruas jalan Mayor. Abd. Karta Wirana dengan total panjang jalan $\pm 650 \mathrm{~m}$ dan diambil panjang $200 \mathrm{~m}$ untuk studi penelitian :

Tipe jalan : :2/2 UD ( 2 lajur 2-arah tak terbagi)

Kelas jalan : Jalan Provinsi

Bahu jalan : 1 Meter

Lebar jalan : 9,8 Meter

Berdasarkan hasil survei hambatan samping dengan traffic count diperoleh jumlah jumlah kendaraan yang berhenti dan parkir di bahu jalan, pejalan kaki (yang sejajar dan menyeberang jalan), kendaraan yang masuk dan keluar jalan serta kendaraan lambat. Sedangkan survei kecepatan dilakukan dengan mencatat waktu tempuh kendaraan yang melewati 200 meter lintasan. Saat kendaraan menyentuh garis 0 bersamaan dengan memulai pencatatan waktu menggunakan stopwatch dan setelah melewati garis 200 meter maka pencatatan dihentikan dan berlangsung selama 20 kali pengamatan pada 2 arah arus lalu lintas.

Bagan alir penelitian sebagaimana Gambar 2.

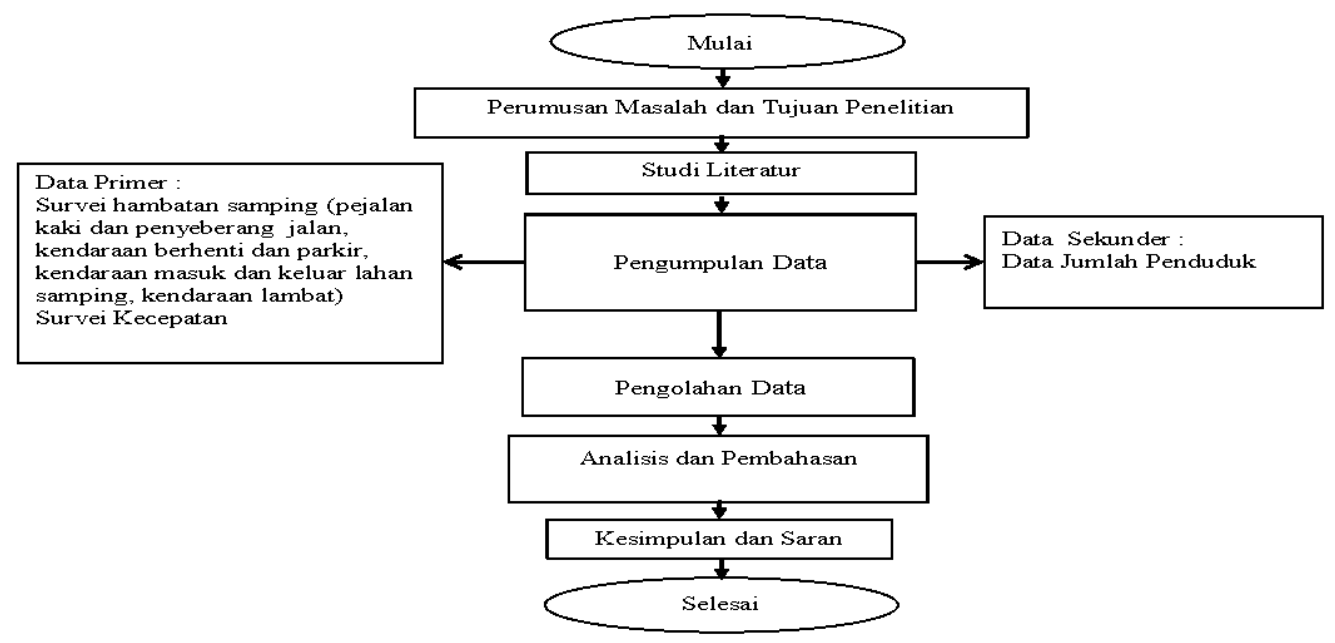

Gambar 2. Bagan Alir Penelitian 


\section{HASIL DAN PEMBAHASAN}

Analisis hambatan samping menggunakan metode MKJI 1997 diperoleh hasil kejadian pada setiap hambatan samping per jam dengan koefisien tiap kejadian pada kelas hambatan samping (kendaraan parkir $=1,0$ kendaraan lambat $=0,4$ pejalan kaki $=0,5$ dan kendaraan keluar masuk $=0,7$ diperoleh total kejadian hambatan samping per hari 200 meter sebagaimana Tabel 3.

Tabel 3. Total Kejadian Hambatan Samping Per Hari 200m

Sumber: Data Olahan, 2020

\begin{tabular}{lc}
\hline Tipe Hambatan Samping & SF/Jam Rabu \\
\hline Pejalan Kaki & 48,39 \\
Kendaraan parkir dan Berhenti & 211,45 \\
Kendaraan Masuk dan Keluar & 790,32 \\
Kendaraan Lambat & 125,18 \\
Total & 1175,34 \\
\hline
\end{tabular}

Berdasarkan Tabel 3, terlihat bahwa total kelas hambatan samping untuk kejadian perhari pada hari Rabu sebesar 1175,34 dengan kejadian hambatan terendah pada pejalan kaki sebesar 48,39 dan kejadian hambatan tertinggi pada kendaraan masuk dan keluar sebesar 790,32. Dapat ditentukan untuk kelas hambatan samping pada ruas Jalan Mayor Abd. Karta Wirana termasuk kelas yang tinggi $(\mathrm{VH})$ dengan frekuensi bobot kejadian melebihi $>900$ kejadian per hari.

Sedangkan hasil analisis kecepatan diperoleh kecepatan saat tidak terganggu pada hari rabu dan kecepatan saat terganggu dari 2 arah yaitu arah pasar baru dan dari arah koni sebagaimana Tabel 4.

Tabel 4. Kecepatan Saat Terganggu dan Tak Terganggu Dari Arah Koni dan Pasar Baru

\begin{tabular}{|c|c|c|c|c|}
\hline No & $\begin{array}{c}\text { Data Kecepatan } \\
\text { terganggu (km/jam) } \\
\text { arah koni }\end{array}$ & $\begin{array}{l}\text { Data Kecepatan } \\
\text { terganggu }(\mathrm{km} / \mathrm{jam}) \\
\text { arah pasar baru }\end{array}$ & $\begin{array}{c}\text { Data Kecepatan tak } \\
\text { terganggu }(\mathrm{km} / \mathrm{jam}) \text { arah } \\
\text { koni }\end{array}$ & $\begin{array}{c}\text { Data Kecepatan tak } \\
\text { terganggu }(\mathrm{km} / \mathrm{jam}) \\
\text { arah pasar baru } \\
\end{array}$ \\
\hline 1 & 12,78 & 12,14 & 25,95 & 21,17 \\
\hline 2 & 11,71 & 10,37 & 31,06 & 23,40 \\
\hline 3 & 10,52 & 10,59 & 29,47 & 29,49 \\
\hline 4 & 12,60 & 11,74 & 20,20 & 38,55 \\
\hline 5 & 10,66 & 11,68 & 31,43 & 29,08 \\
\hline 6 & 10,02 & 12,04 & 34,48 & 35,50 \\
\hline 7 & 12,35 & 11,81 & 36,40 & 25,53 \\
\hline 8 & 12,07 & 11,69 & 27,90 & 38,53 \\
\hline 9 & 12,45 & 11,17 & 27,25 & 35,30 \\
\hline 10 & 12,59 & 10,25 & 32,53 & 33,25 \\
\hline Max & \multicolumn{2}{|c|}{12,78} & \multicolumn{2}{|c|}{38,55} \\
\hline Min & \multicolumn{2}{|c|}{10,02} & \multicolumn{2}{|c|}{20,20} \\
\hline Mean & \multicolumn{2}{|c|}{11,56} & \multicolumn{2}{|c|}{30,32} \\
\hline Penurunan (\%) & & & & \\
\hline
\end{tabular}

Berdasarkan tabel diperoleh kecepatan maksimum saat terganggu sebesar 12,78 km/jam dan kecepatan minimum sebesar 10,02 km/jam serta rata-rata kecepatan saat terganggu sebesar 11,56 km/jam. demikian juga dengan kecepatan maksimum saat tak terganggu sebesar 38,55 km/jam dan kecepatan minimum sebesar 20,20 km/jam serta rata-rata kecepatan saat tak terganggu sebesar $30,32 \mathrm{~km} / \mathrm{jam}$. Dari kedua kecepatan terganggu dan tak terganggu tersebut diperoleh persentase penurunan kecepatan yang sangat signifikan sebesar $61,87 \%$ dengan ini menyatakan hambatan samping sangatlah besar pengaruhnya terhadap kecepatan, ditandai dengan semakin menurunnya kecepatan kendaraan.

Kemudian data kecepatan saat terganggu dan tak terganggu diolah menggunakan metode statistik sebagaimana langkah tahapan membuat distribusi frekuensi, dengan membuat interval kecepatan dan diperoleh distribusi kumulatif kecepatan sebagaimana Gambar 3. 
Emelda Raudhati dan Ellyta Mona, Analisis Kecepatan Kendaraan Akibat Hambatan Samping (Studi Kasus: Jl. Mayor Abd. Karta Wirana Kota Jambi di sekitar Lippo Mall)

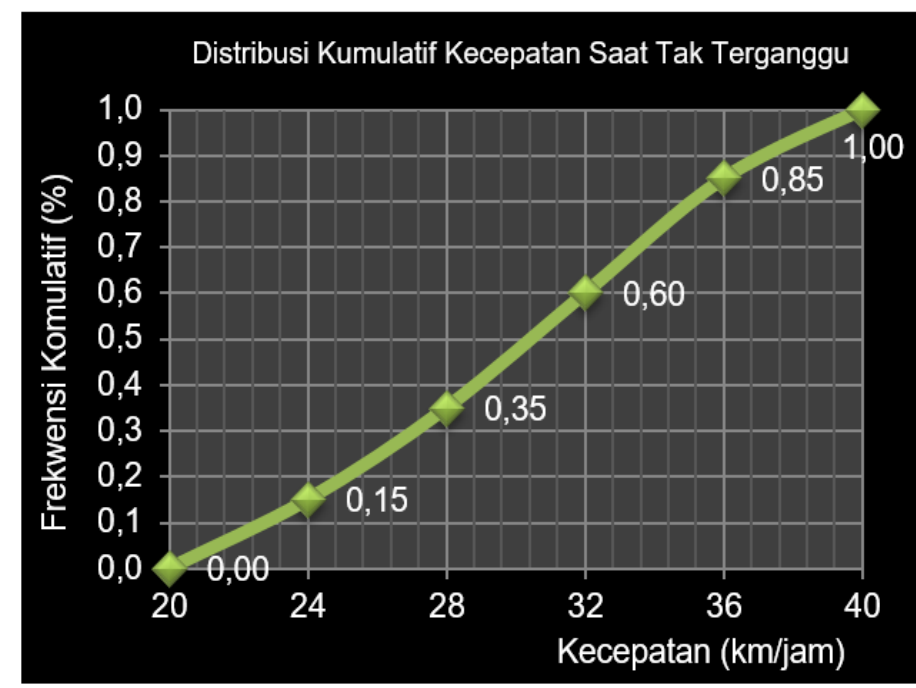

(a)

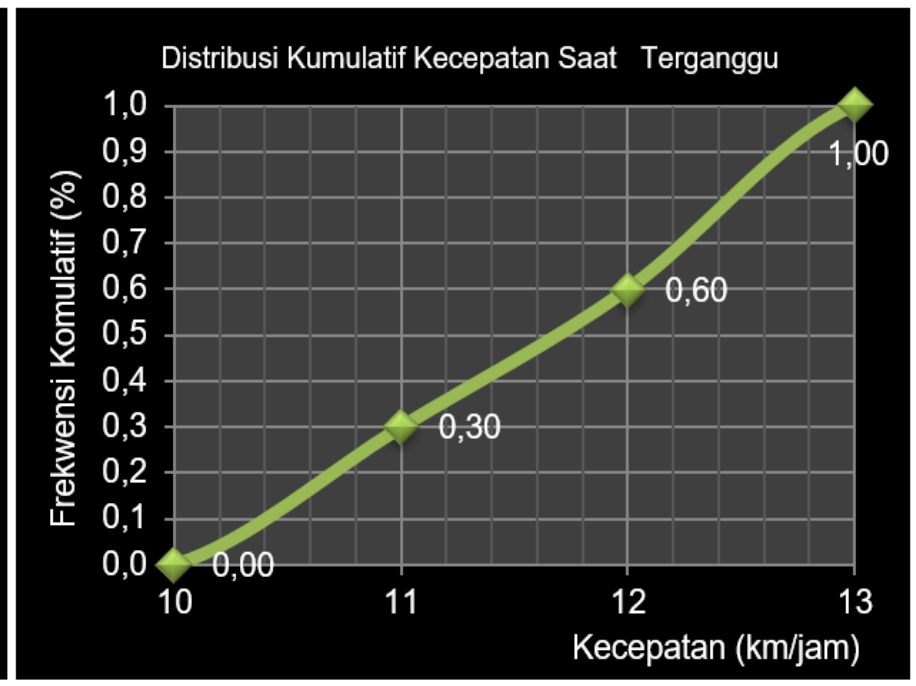

(b)

Gambar 3. Distribusi Kumulatif Kecepatan Saat (a) Tidak Terganggu (b) Terganggu Dari Arah Koni dan Pasar Baru

Berdasarkan Gambar 3, terlihat bahwa distribusi kumulatif kecepatan saat tak terganggu dengan kecepatan terendah pada interval $20-24 \mathrm{~km} / \mathrm{jam}$ dan tertinggi $36-40 \mathrm{~km} / \mathrm{jam}$. Sedangkan distribusi kumulatif kecepatan saat terganggu dengan kecepatan terendah interval $10-11 \mathrm{~km} / \mathrm{jam}$ dan tertinggi 12 - $13 \mathrm{~km} / \mathrm{jam}$.

\section{SIMPULAN}

Berdasarkan hasil penelitian terkait kecepatan dan hambatan samping maka dapat disimpulkan bahwa total kelas hambatan samping untuk kejadian perhari pada hari rabu sebesar 1175,34 dengan kejadian hambatan terendah pada pejalan kaki sebesar 48,39 dan kejadian hambatan tertinggi pada kendaraan masuk dan keluar sebesar 790,32. Dapat ditentukan untuk kelas hambatan samping pada ruas Jalan Mayor Abd. Karta Wirana sebagaimana MKJI 1997 menyatakan termasuk kelas yang tinggi $(\mathrm{VH})$ dengan frekuensi bobot kejadian melebihi $>900$ kejadian per hari. Sedangkan kecepatan saat terganggu diperoleh rata-rata 11,56 km/jam dan kecepatan saat tak terganggu dengan ratarata $30,32 \mathrm{~km} / \mathrm{jam}$, dari kedua kecepatan tersebut terjadi penurunan kecepatan yang sangat signifikan sebesar $61,87 \%$, dengan ini menyatakan hambatan samping sangatlah besar pengaruhnya terhadap kecepatan, ditandai dengan semakin menurunnya kecepatan kendaraan. sedangkan distribusi kumulatif kecepatan saat tak terganggu terendah pada interval 20 - $24 \mathrm{~km} / \mathrm{jam}$ dan tertinggi 36 - $40 \mathrm{~km} / \mathrm{jam}$, dan distribusi kumulatif kecepatan saat terganggu terendah pada interval $10-11 \mathrm{~km} / \mathrm{jam}$ dan tertinggi $12-13 \mathrm{~km} / \mathrm{jam}$.

\section{DAFTAR PUSTAKA}

Clarkson H. Oglesby, R Gary Hicks, 1999. Teknik Jalan Raya, Penerbit Erlangga

Direktorat Jenderal Bina Marga, 1997. Manual Kapasitas Jalan Indonesia (MKJI), Jakarta

Hobbs, F.D., 1995, Perencanaan dan Teknik Lalu Lintas, Penerbit UGM, Yogyakarta.

Irfan, 2017. Pengaruh Hambatan Samping terhadap Kecepatan dan Arus Lalu Lintas, Jurnal Teknik Sipil dan Teknologi Konstruksi Vol. 3 No. 4 April 2017.

Sudjana, 1996. Metoda Statistika, Penerbit Tarsito, Bandung.

Tamin O.Z, 2000. Perencanaan dan Pemodelan Transportasi, ITB, Bandung.

Tataming E S, Theo K Sendao, Oscar H. Raseke, Sompie Diantje, 2015. Analisis Besar Kontribusi Hambatan Samping terhadap Kecepatan dengan Menggunakan Model Regresi Linier Berganda, Jurnal Sipil Statik Vol. 2 No. 1 Januari 2014 (29-36) ISSN: 2337 -6732.

Winayati, 2016. Analisis Pengaruh Kecepatan dan Hambatan Samping Terhadap Kapasitas Jalan, Jurnal Teknik Sipil Siklus. Vol 2, No. 2, Oktober 2016. 